\title{
IL-17 promotes keratinocyte proliferation via the downregulation of $\mathrm{C} / \mathrm{EBP} \alpha$
}

\author{
WEI-YUAN MA ${ }^{1}$, KUN JIA ${ }^{2}$ and YAN ZHANG ${ }^{2}$ \\ ${ }^{1}$ Department of Dermatology, Qilu Hospital; ${ }^{2}$ School of Medicine, Shandong University, Jinan, Shandong 250012, P.R.China
}

Received October 26, 2014; Accepted November 5, 2015

DOI: $10.3892 /$ etm.2015.2939

\begin{abstract}
Psoriasis vulgaris is a common chronic inflammatory skin disease characterized by the hyperproliferation and abnormal differentiation of keratinocytes. CCATT/enhancer binding protein $\alpha(\mathrm{C} / \mathrm{EBP} \alpha)$ is abundant in the epidermis and is associated with the proliferation of keratinocytes. However, the role of $\mathrm{C} / \mathrm{EBP} \alpha$ in the proliferation of keratinocytes and the pathogenesis of psoriasis vulgaris are yet to be elucidated. In the present study, using two-step immunohistochemistry, the expression levels of $\mathrm{C} / \mathrm{EBP} \alpha$ and $\mathrm{Ki}-67$ were examined in skin biopsies harvested from 30 patients with psoriasis vulgaris and 30 healthy control subjects. The proliferation index (PI) was calculated and the correlation between $\mathrm{C} / \mathrm{EBP} \alpha$ expression levels and the PI was assessed using Pearson's correlation coefficient. In addition, the effect on $\mathrm{HaCaT}$ immortalized human keratinocytic cells of treatment with various concentrations of interleukin (IL)-17 was investigated. Subsequently, cell proliferation rates were examined using a Cell Counting kit-8 assay and the mRNA and protein expression levels of $\mathrm{C} / \mathrm{EBP} \alpha$ were analyzed using semiquantitative reverse transcription-polymerase chain reaction and western blotting, respectively, in order to analyze the effects of IL-17 stimulation on $\mathrm{C} / \mathrm{EBP} \alpha$ expression levels. $\mathrm{C} / \mathrm{EBP} \alpha$ expression was predominantly detected in the cytoplasm of the keratinocytes and $\mathrm{C} / \mathrm{EBP} \alpha$ expression levels were significantly lower in the psoriatic lesions $(\mathrm{P}<0.05)$, as compared with the control group. An inverse correlation was detected between the expression levels of $\mathrm{C} / \mathrm{EBP} \alpha$ and the PI in the psoriatic lesions. Furthermore, a significant increase in the cell proliferation rate and significant reductions in the mRNA
\end{abstract}

Correspondence to: Dr Wei-Yuan Ma, Department of Dermatology, Qilu Hospital, Shandong University, 107 West Wenhua Road, Jinan, Shandong 250012, P.R. China

E-mail: weiyuanmajn@163.com

Abbreviations: IL-17, interleukin-17; C/EBP $\alpha$, CCAAT/enhancer binding protein $\alpha$

Key words: psoriasis vulgaris, keratinocyte, proliferation, CCATT/enhancer binding protein $\alpha$, interleukin-17 and protein expression levels of $\mathrm{C} / \mathrm{EBP} \alpha$ were detected in $\mathrm{HaCaT}$ cells following treatment with IL-17. These results demonstrated that $\mathrm{C} / \mathrm{EBP} \alpha$ may act as a downstream target of IL-17 and may be associated with the pathogenesis of psoriasis.

\section{Introduction}

Psoriasis vulgaris is a chronic inflammatory disorder characterized by the hyperproliferation and abnormal differentiation of keratinocytes and the infiltration of inflammatory cells into the dermis and epidermis. Although its exact pathogenesis is yet to be elucidated, psoriasis vulgaris is associated with various genetic, immunological, psychological and environmental factors (1). T-cell-mediated specific and nonspecific immune disorders associated with the genetic background of the patient have been demonstrated to have a central role in the pathogenesis of psoriasis (2). T-helper (Th)17 cells, which are a newly discovered subset of Th cells, are capable of secreting an important pro-inflammatory cytokine, interleukin (IL)-17, and the Th-17/IL-17 axis has a key role in the immunopathogenesis of psoriasis vulgaris $(3,4)$.

The CCAAT/enhancer binding protein (C/EBP) family, which consists of a group of basic transcription factors containing a leucine zipper structure, is critical to the proliferation and differentiation of various cell types (5). $\mathrm{C} / \mathrm{EBP} \alpha$, which was the first cloned member of the C/EBP family with 358 amino acid residues, contains a C-terminal leucine-zipper protein interaction domain, a basic DNA binding region and an N-terminal transcriptional activation domain (6). $\mathrm{C} / \mathrm{EBP} \alpha$ is expressed in various highly differentiated cells and tissues, including peripheral blood mononuclear cells, and adipose, liver and lung tissues (7). Previous studies have demonstrated that $\mathrm{C} / \mathrm{EBP} \alpha$ is expressed in every layer of the epidermis; therefore, $\mathrm{C} / \mathrm{EBP} \alpha$ may regulate the proliferation and differentiation of keratinocytes $(8,9)$.

In the present study, the expression levels of $\mathrm{C} / \mathrm{EBP} \alpha$ and $\mathrm{Ki}-67$ were investigated in psoriasis vulgaris lesions using immunohistochemistry, and the proliferation index (PI) was subsequently calculated to explore the correlation between $\mathrm{C} / \mathrm{EBP} \alpha$ expression levels and PI. In addition, the mRNA and protein expression levels of $\mathrm{C} / \mathrm{EBP} \alpha$ and the cell proliferation rate were examined in $\mathrm{HaCaT}$ cells, an immortalized human keratinocytic cell line, following treatment with various concentrations of IL-17 in vitro. 


\section{Materials and methods}

Patients and skin biopsies. Skin biopsies were obtained from 30 patients with active stage psoriasis vulgaris, including 14 males and 16 females aged 13-45 years (mean, $27.77 \pm 8.64$ years), who presented at the Department of Dermatology at Qilu Hospital (Jinan, China). None of the participants had previously been diagnosed with another systemic disease and no local or systematic therapy was administered for $\geq 2$ months prior to the biopsy. Control skin samples were obtained from 30 gender- and age-matched healthy participants (14 males and 16 females) aged 9-51 years old (mean, $31.80 \pm 14.86$ years). Written informed consent was provided by all participants prior to the skin biopsies and the present study was approved by the Qilu Hospital Ethics Committee of Shandong University.

Immunohistochemistry. Following excision, the skin samples were immediately fixed in $10 \%$ neutral formaldehyde, embedded in paraffin and serially cut into $3-\mu$ m-thick sections. Subsequently, the sections were deparaffinized with xylene and rehydrated using a graded ethanol series. Antigen retrieval was conducted by incubation with $1 \mathrm{mM}$ ethylenediaminetetraacetic acid (EDTA) buffer $(\mathrm{pH} 8.0)$ at $120^{\circ} \mathrm{C}$ under high pressure for $5 \mathrm{~min}$. Endogenous peroxidase activity was terminated using 3\% hydrogen peroxide solution and the sections were subsequently blocked with $5 \%$ goat serum (C-0005; BIOSS; Beijing, China) to prevent nonspecific background staining. Following this, the sections were incubated at $37^{\circ} \mathrm{C}$ for $1 \mathrm{~h}$ with rabbit anti-human $\mathrm{C} / \mathrm{EBP} \alpha$ polyclonal antibody (1:100; bs-16030R) and mouse anti-human Ki-67 ready-to-use monoclonal antibody $(1: 100$; bs-2130R; both BIOSS). After washing three times with phosphate-buffered saline, sections were incubated using a PV-6000 Polymer Detection system (ZSGB-Bio, Beijing, China), according to the manufacturer's protocol, stained with 3,3'-diaminobenzidine substrate (ZSGB-Bio) for color development and subsequently counterstained with Harris' hematoxylin (Beyotime Institute of Biotechnology, Jiangsu, China) for examination under a light microscope (DM1000 LED; Leica Microsystems, Inc., Buffalo Grove, IL, USA). Keratinocytes were deemed positive for $\mathrm{C} / \mathrm{EBP} \alpha$ or $\mathrm{Ki}-67$ expression if yellow to brown granules were detected in the cytoplasm or nucleus, respectively. Three fields were randomly selected under high magnification $(x 400)$ and the mean gray value of the positive area was analyzed using Image Pro Plus (IPP) software, version 6.0 (Media Cybernetics, Inc., Rockville, MD, USA), where a high grey value indicated lower expression levels. Five representative fields with the highest number of positive cells were counted in each section (magnification, $\mathrm{x} 400$ ) and the PI was calculated as the percentage of total epidermal cells that were Ki-67-positive.

Cell culture. HaCaT immortalized human keratinocyte cell line was purchased from the American Type Culture Collection (Manassas, VA, USA). HaCaT cells were cultured in Dulbecco's modified Eagle's medium (DMEM) (Gibco; Thermo Fisher Scientific, Inc., Waltham, MA, USA) supplemented with $10 \%$ fetal bovine serum $(\mathrm{vol} / \mathrm{vol}), 100 \mathrm{U} / \mathrm{ml}$ penicillin and $100 \mu \mathrm{g} / \mathrm{ml}$ streptomycin (C0222; Beyotime Institute of
Biotechnology) in a humidified incubator containing $5 \% \mathrm{CO}_{2}$ at $37^{\circ} \mathrm{C}$. Cells were digested with $0.25 \%$ trypsin $/ 0.02 \%$ EDTA (1:1) solution (C0203; Beyotime Institute of Biotechnology) and passaged (1:2) every 2-3 days. Subsequently, the HaCaT cells were cultured in 12 -well plates $\left(1 \times 10^{5}\right.$ cells $\left./ \mathrm{ml}\right)$ and grown to $60-70 \%$ confluence, prior to stimulation with 50,70 and $90 \mathrm{ng} / \mathrm{ml} \mathrm{IL-17}$ for $24 \mathrm{~h}$. Following treatment, cells were harvested for RNA isolation and protein extraction, respectively. DMEM was simultaneously used without IL-17 to treat the control group. Experiments were performed in triplicate.

Cell Counting kit-8 Assay. A total of $5 \times 10^{3} \mathrm{HaCaT}$ cells $/ \mathrm{ml}$ in the logarithmic growth phase were cultured in 96-well plates. At $60-70 \%$ confluence, cells were treated with 50,70 or $90 \mathrm{ng} / \mathrm{ml} \mathrm{IL}-17$ for $24 \mathrm{~h}$. Subsequently, cells were incubated with CCK-8 reagent at $37^{\circ} \mathrm{C}$ for $2 \mathrm{~h}$, according to the manufacturer's protocol (Dojindo Molecular Technologies, Inc., Kumamoto, Japan). A Varioskan ${ }^{\mathrm{TM}}$ Flash microplate reader (Thermo Fisher Scientific, Inc.) was used to measure the optical density (OD) at $450 \mathrm{~nm}$. Cell viability (\% of control) was calculated as follows: $\left(\mathrm{OD}_{\text {test }}-\mathrm{OD}_{\text {blank }}\right) /\left(\mathrm{OD}_{\text {control }}-\mathrm{OD}_{\text {blank }}\right)$. Experiments were performed in sextuplicate.

Semi-quantitative reverse transcription-polymerase chain reaction (RT-PCR). Following treatment with IL-17 for $24 \mathrm{~h}$, total RNA was isolated from the HaCaT cells using an RNAiso Plus kit (Takara Biotechnology Co., Ltd., Dalian, China), according to the manufacturer's protocol, and detected using a Nanodrop ${ }^{\mathrm{TM}} 2000$ spectrophotometer at $260 \mathrm{~nm}$ (Nanodrop; Thermo Fisher Scientific, Inc.). A total of $1 \mu \mathrm{g}$ RNA was reverse transcribed into cDNA using oligodeoxythymine nucleotide primers and subsequently amplified using a Power RT kit (BioTeke Corporation, Beijing, China). Specific primer pairs were synthesized by Sangon Biotech Co., Ltd. (Shanghai, China) and their sequences are listed in Table I. PCR was performed using a $50-\mu 1$ system containing: $25 \mu 12 \mathrm{X}$ Super Taq PCR MasterMix (PR1732; BioTeke Corporation), $2.5 \mu \mathrm{l}$ forward and reverse primers, $10 \mu \mathrm{l}$ template and $10 \mu \mathrm{l}$ triple-distilled water. Reaction conditions were as follows: $95^{\circ} \mathrm{C}$ for $5 \mathrm{~min}$, followed by 35 cycles of $95^{\circ} \mathrm{C}$ for $1 \mathrm{~min}, 60^{\circ} \mathrm{C}$ for $45 \mathrm{sec}, 72^{\circ} \mathrm{C}$ for $45 \mathrm{sec}$, and $72^{\circ} \mathrm{C}$ for $10 \mathrm{~min}$. The amplified PCR products were separated by $2 \%$ agarose gel electrophoresis. The sizes of the C/EBP $\alpha$ and $\beta$-actin fragments were 375 and $495 \mathrm{bp}$, respectively. Ethidium bromide-stained PCR products were visualized using an ultraviolet transilluminator $\left(\mathrm{Tanon}^{\mathrm{TM}}\right.$ 2500R; Tanon Science and Technology Co., Ltd., Shanghai, China) and gray values of the DNA bands were simultaneously measured using the automatic image analyzer software. Relative gray values were measured as the ratio of gray value between C/EBP $\alpha$ and $\beta$-actin.

Western blotting. HaCaT cells were dissolved in lysis buffer containing $1 \mathrm{mM}$ phenylmethanesulfonyl fluoride (Cell Lysis Buffer for Western and IP; Beyotime Institute of Biotechnology) on ice. Samples were centrifuged at $12,000 \mathrm{x} \mathrm{g}$ for $5 \mathrm{~min}$ and the total protein content in the supernatant was analyzed using an Enhanced BCA Protein Assay kit (Beyotime Institute of Biotechnology). A total of $30 \mu \mathrm{g}$ protein from the cell lysates was separated by $10 \%$ sodium dodecyl 
Table I. Primer sequences.

\begin{tabular}{lll}
\hline Gene & \multicolumn{1}{c}{ Primer } & \multicolumn{1}{c}{ Sequence $\left(5^{\prime}-3^{\prime}\right)$} \\
\hline C/EBP $\alpha$ & Upstream & CACCGCTCCAATGCCTAC \\
& Downstream & CCCATCGCAGTGAGTTCCG \\
\multirow{3}{*}{-actin } & Upstream & AAGTACTCCGTGTGGATCGG \\
& Downstream & ATGCTATCACCTCCCCTGTG
\end{tabular}

$\mathrm{C} / \mathrm{EBP} \alpha, \mathrm{CCATT} / \mathrm{enhancer}$ binding protein $\alpha$

sulfate-polyacrylamide gel electrophoresis and transferred to a polyvinylidene difluoride (PVDF) membrane. The PVDF membrane was subsequently blocked with $5 \%$ skimmed milk at room temperature for $1 \mathrm{~h}$ and incubated at $4^{\circ} \mathrm{C}$ overnight with rabbit anti-human $\mathrm{C} / \mathrm{EBP} \alpha$ polyclonal antibody $(1: 400$; bs-16030R; BIOSS), or mouse anti-human anti- $\beta$-actin antibody $(1: 1,000$; sc-47778; Santa Cruz Biotechnology, Inc., Dallas, TX, USA). After washing with $0.01 \mathrm{M}$ Tris-buffered saline containing $0.1 \%$ Tween-20, the membrane was incubated with horseradish peroxidase-labeled goat-anti-rabbit or goat-anti-mouse immunoglobulin $\mathrm{G}$ antibody (1:1,000; E030120-01; EarthOx Life Sciences, Millbrae, CA, USA) at room temperature for $1 \mathrm{~h}$. A standard enhanced chemiluminescence reaction (Sangon Biotech Co., Ltd., Shanghai, China) was performed, according to the manufacturer's protocol, and densitometric analysis of the band intensity

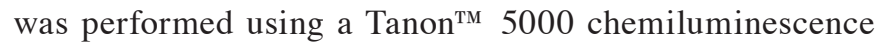
imaging analysis system (Tanon Science and Technology Co., Ltd.). Relative protein expression levels were calculated as gray value ratios as follows: $\mathrm{C} / \mathrm{EBP} \alpha$ integrated option density (IOD) $/ \beta$-actin IOD.

Statistical analysis. SPSS software, version 19.0 (SPSS, Inc., Chicago, IL, USA) was used for all statistical analyses. Data were expressed as the mean \pm standard deviation. The intensity of immunohistochemical staining of $\mathrm{C} / \mathrm{EBP} \alpha$ between the psoriasis and control groups was analyzed using Student's t-test. Analyses of the correlation between $\mathrm{C} / \mathrm{EBP} \alpha$ expression levels and PI in the psoriatic lesions were performed using Pearson's correlation coefficient. mRNA and protein expression levels of $\mathrm{C} / \mathrm{EBP} \alpha$ were analyzed between the psoriasis and control groups following the administration of various concentrations of IL-17 using one-way analysis of variance with Student-Newman-Keuls post-hoc analysis. $\mathrm{P}<0.05$ was considered to indicate a statistically significant difference.

\section{Results}

Immunohistochemical staining of $C / E B P \alpha$ in psoriatic lesions. $\mathrm{C} / \mathrm{EBP} \alpha$ was expressed in the cytoplasm of the majority of keratinocytes and in the whole epidermis of the healthy control skin samples, with sporadic expression detected in the basal layer and enhanced expression levels detected in the stratum corneum. Staining of $\mathrm{C} / \mathrm{EBP} \alpha$ was weaker in the psoriasis vulgaris group, as compared with the control group. Immunohistochemical staining demonstrated the grey value of $\mathrm{C} / \mathrm{EBP} \alpha$ was $51.94 \pm 7.60$ in the control group, as compared
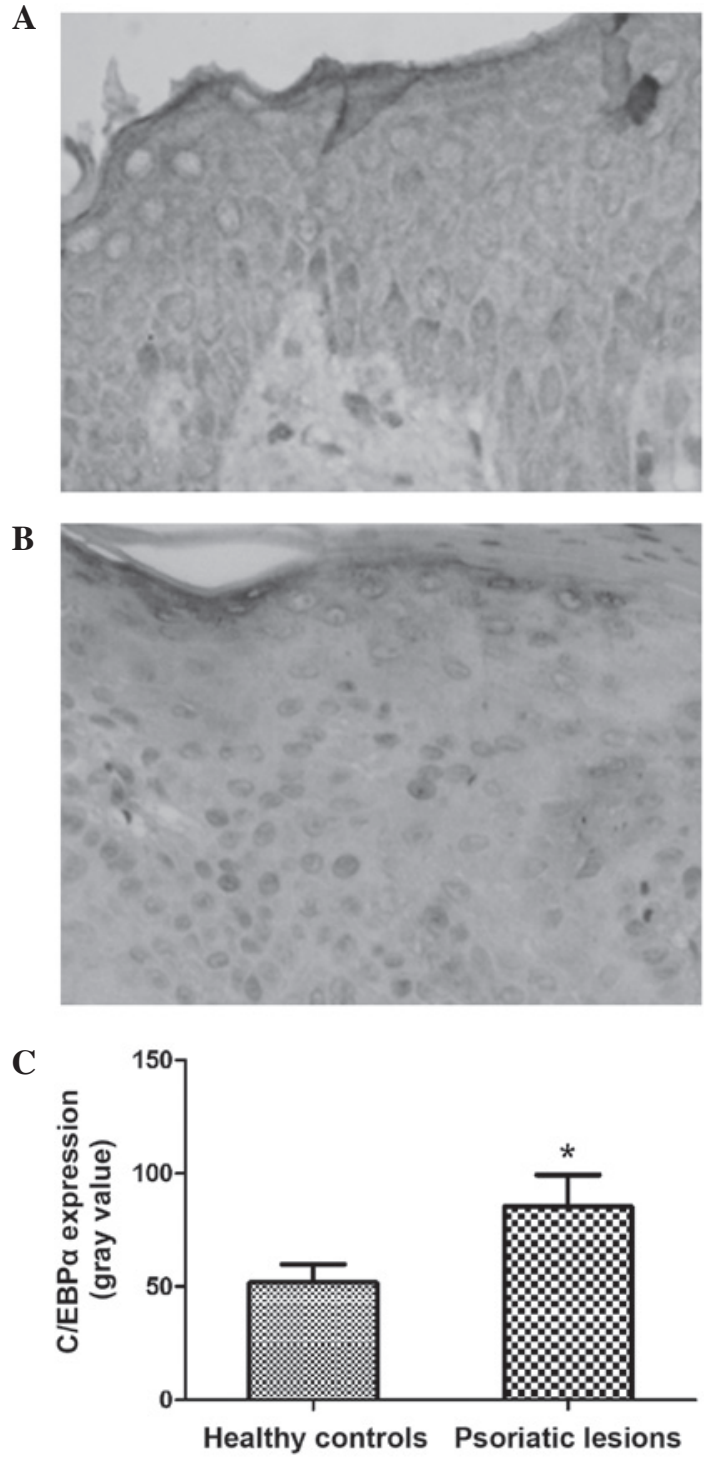

Figure 1. Immunohistochemical staining of $\mathrm{C} / \mathrm{EBP} \alpha$ in (A) healthy control skin samples and (B) psoriatic lesions. Magnification, x100. (C) Expression levels of $\mathrm{C} / \mathrm{EBP} \alpha$ in psoriatic lesions and healthy control skin samples, as determined from the grey value, where higher grey values indicate lower expression levels. $\mathrm{P}<0.01$ vs. healthy controls. C/EBP, CCATT/enhancer binding protein.

with $85.44 \pm 13.88$ in the psoriasis vulgaris group. Therefore, significantly reduced $\mathrm{C} / \mathrm{EBP} \alpha$ expression levels were detected in the psoriatic lesions $(\mathrm{t}=7.819, \mathrm{P}<0.01)$, as compared with the control skin samples (Fig. 1).

Correlation between C/EBP $\alpha$ expression levels and PI. Immunohistochemical staining demonstrated that Ki-67 was predominantly expressed in the cytoplasm of keratinocytes and was sporadically expressed in the basal layer of the control skin samples. Ki-67-positive cells were detected in the basal layer and, notably, in the middle and lower parts of the stratum spinosum of psoriasis vulgaris lesions. The PI was significantly increased in the psoriasis vulgaris group (0.20 0.09$)$, as compared with $0.66 \pm 0.03$ in the control group $(t=4.535$; $\mathrm{P}<0.01$; Fig. 2A). Pearson correlation analysis demonstrated that there was a significant positive correlation between the grey values of $\mathrm{C} / \mathrm{EBP} \alpha$ and the PI ( $\mathrm{r}=0.654, \mathrm{P}<0.01$; Fig. $2 \mathrm{~B}$ ), 


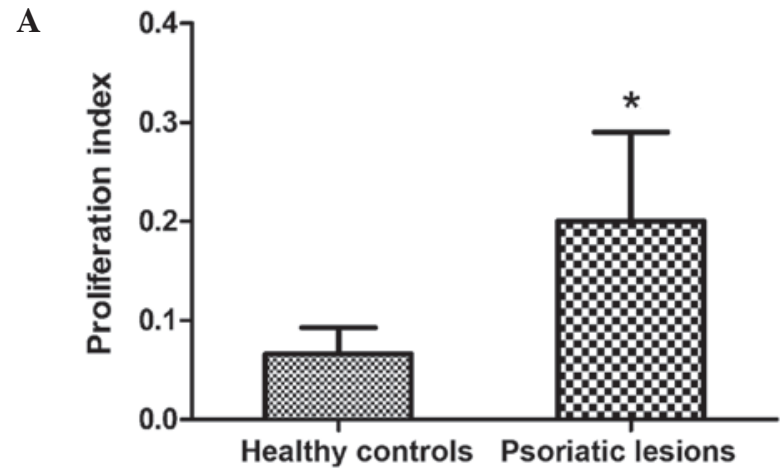

B

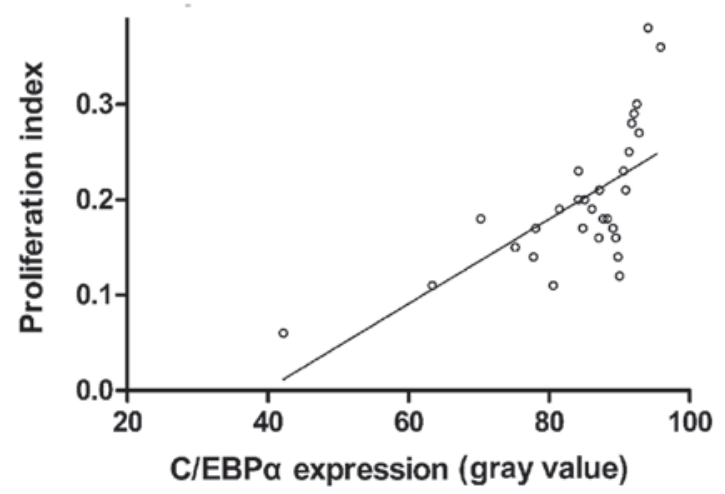

Figure 2. (A) Proliferation indices of psoriatic lesions and healthy control skin samples. (B) Correlation between $\mathrm{C} / \mathrm{EBP} \alpha$ expression levels (grey value; inversely proportional to expression level) and proliferation indices in psoriatic lesions. ${ }^{*} \mathrm{P}<0.01$ vs. healthy controls. $\mathrm{C} / \mathrm{EBP}, \mathrm{CCATT} / \mathrm{enhancer}$ binding protein.

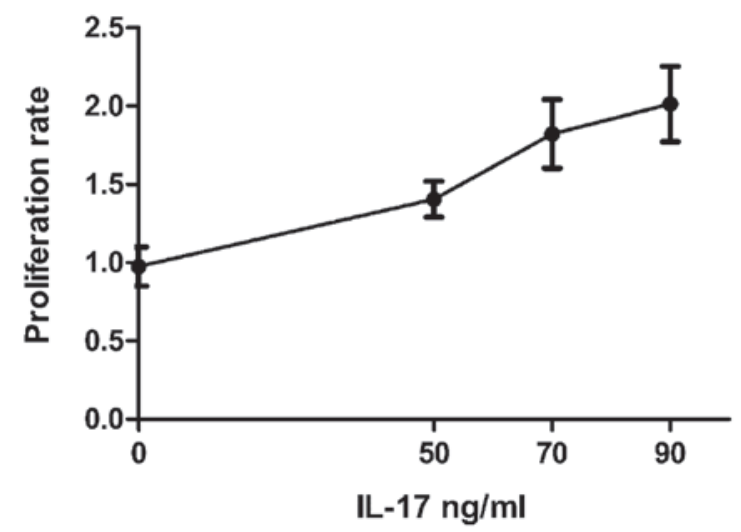

Figure 3. HaCaT cell proliferation rates following treatment with 50,70 or $90 \mathrm{ng} / \mathrm{ml} \mathrm{IL-17} \mathrm{for} 24 \mathrm{~h}$, as determined by a Cell Counting kit- 8 assay. IL, interleukin.

which implied that the expression levels of $\mathrm{C} / \mathrm{EBP} \alpha$ in the keratinocytes of psoriasis vulgaris were inversely correlated with the PI.

Effect of IL-17 treatment on the proliferation of HaCaT cells and $C / E B P \alpha$ expression levels. In the in vitro experiment, immortalized human keratinocytic HaCaT cells were treated with 50, 70 and $90 \mathrm{ng} / \mathrm{ml} \mathrm{IL-17}$ for $24 \mathrm{~h}$. As compared with the control group, IL-17 treatment significantly increased the proliferation of $\mathrm{HaCaT}$ cells in a concentration-dependent manner (Fig.3). Following culture with 50, 70 and 90 ng/ml IL-17,
A

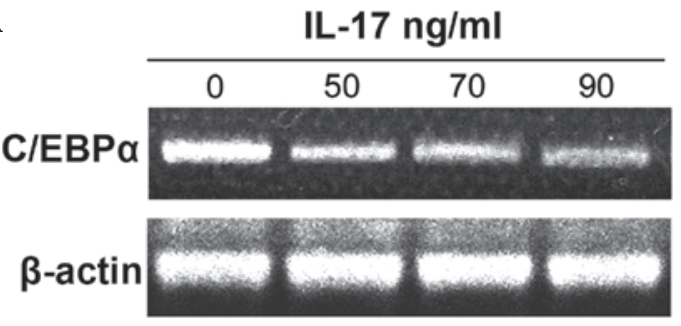

B

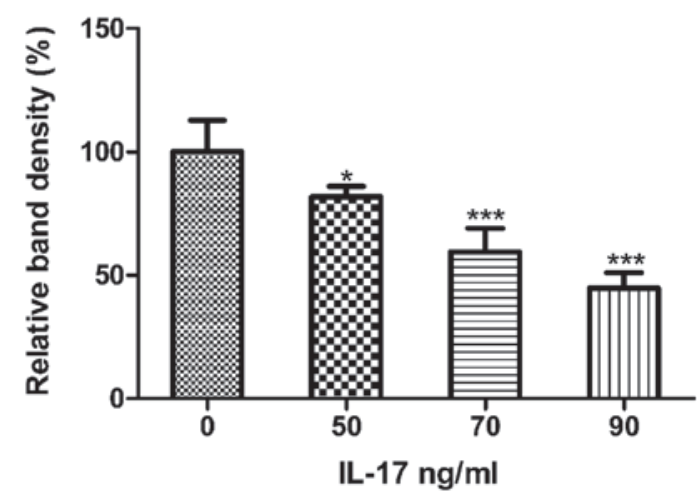

C

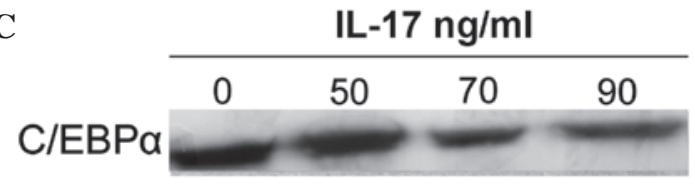

$\beta$-actin

D

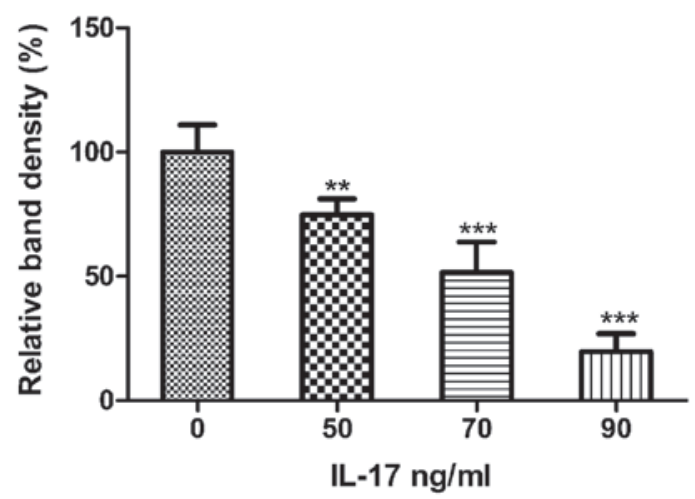

Figure 4. C/EBP $\alpha$ mRNA expression levels in $\mathrm{HaCaT}$ cells following treatment with 50,70 or $90 \mathrm{ng} / \mathrm{ml}$ IL-17 for $24 \mathrm{~h}$. (A) Representative reverse transcription-polymerase chain reaction result of $\mathrm{C} / \mathrm{EBP} \alpha \mathrm{mRNA}$ expression levels in HaCaT cells. (B) $\mathrm{C} / \mathrm{EBP} \alpha$ mRNA expression levels were significantly downregulated following treatment with 50,70 or $90 \mathrm{ng} / \mathrm{ml} \mathrm{IL-17}$ for 24 h. (C) Representative western blot of $\mathrm{C} / \mathrm{EBP} \alpha$ protein expression levels in $\mathrm{HaCaT}$ cells. (D) $\mathrm{C} / \mathrm{EBP} \alpha$ protein expression levels were significantly downregulated following treatment with 50,70 or $90 \mathrm{ng} / \mathrm{ml} \mathrm{IL-17}$ for 24 h. ${ }^{*} \mathrm{P}<0.05,{ }^{* *} \mathrm{P}<0.01,{ }^{* * * *} \mathrm{P}<0.001$ vs. the control (0 ng/ml IL-17) group. $\mathrm{C} / \mathrm{EBP}, \mathrm{CCATT} / \mathrm{enhancer}$ binding protein; IL, interleukin.

semiquantitative RT-PCR and western blot analyses were performed using a $\beta$-actin housekeeping control in order to examine the mRNA and protein expression levels of $\mathrm{C} / \mathrm{EBP} \alpha$. The results demonstrated that, as compared with the control group, 50, 70 and $90 \mathrm{ng} / \mathrm{ml}$ IL-17 significantly reduced the mRNA ( $\mathrm{q}=4.11, \mathrm{P}<0.05 ; \mathrm{q}=9.12, \mathrm{P}<0.001 ; \mathrm{q}=12.44, \mathrm{P}<0.001$, respectively) and protein $(\mathrm{q}=5.293, \mathrm{P}<0.01 ; \mathrm{q}=10.17, \mathrm{P}<0.001$; 
$q=16.82, \mathrm{P}<0.001$, respectively) expression levels of $\mathrm{C} / \mathrm{EBP} \alpha$ in a concentration-dependent manner (Fig. 4).

\section{Discussion}

Psoriasis vulgaris is a chronic inflammatory disease characterized by a thickened epidermis, hyperproliferation and parakeratosis of keratinocytes and marked inflammatory cell infiltration. It is hypothesized that the abnormal proliferation and differentiation of keratinocytes in psoriatic lesions is associated with the activation of $\mathrm{T}$ cells by external stimuli, which subsequently recognize a self-antigen and lead to an immune response, in which the Th-17/IL-17 axis has an important role (10). Th17 cells, which are named according to their secretion of IL-17, are a newly reported subtype of $\mathrm{CD}^{+} \mathrm{T}$ cells that gather in psoriatic lesions (11). Significantly increased expression levels of IL-17 have been detected in psoriatic lesions, as compared with samples from control skin and skin surrounding psoriatic lesions (11). Furthermore, the administration of IL-17 monoclonal antibody to patients with psoriasis is capable of quickly and effectively alleviating the clinical symptoms, improving pathological characteristics and attenuating keratinocyte proliferation and inflammatory cell infiltration into the lesions $(12,13)$. In the form of homogenous or heterogeneous dimers, IL-17 binds to its IL-17 receptor (IL-17R) and subsequently activates the signaling pathways of phosphoinositide 3-kinase (PI3K), nuclear factor (NF)- $\mathrm{B}$ and mitogen-activated protein kinase in order to regulate cell proliferation $(14,15)$. A previous study, based on the upregulation of IL-17R in the keratinocytes of psoriatic lesions, has demonstrated that the administration of IL-17R receptor antagonists may rapidly control the symptoms of psoriasis, and reduce the psoriasis area and severity index (16). This suggests that IL-17 may mediate this immune disorder, resulting in the excessive proliferation and differentiation of keratinocytes.

$\mathrm{C} / \mathrm{EBP} \alpha$, which is selectively expressed in a variety of tissue cells, interacts with various tissue-specific transcription factors in order to regulate proliferation and differentiation (17). Furthermore, $\mathrm{C} / \mathrm{EBP} \alpha$ may be an important negative regulator of cell proliferation. Reduced $\mathrm{C} / \mathrm{EBP} \alpha$ expression levels have been detected in various types of cancer, including lung, breast, liver and other epithelial tumors; therefore, $\mathrm{C} / \mathrm{EBP} \alpha$ may be associated with the pathogenesis of cancer (18-20). C/EBP $\alpha$ is abundantly expressed in normal skin tissue and reduced $\mathrm{C} / \mathrm{EBP} \alpha$ expression levels in some skin tumors have been correlated with uncontrolled cell proliferation and tumor development, in which the re-expression and enhanced expression of $\mathrm{C} / \mathrm{EBP} \alpha$ was demonstrated to inhibit hyperproliferation (21). Previous studies have demonstrated that $\mathrm{C} / \mathrm{EBP} \alpha$ protein dimers, rather than the leucine zipper domain, directly interact with various cell cycle-related proteins in order to control the cell cycle process $(22,23)$. $\mathrm{C} / \mathrm{EBP} \alpha$ is capable of regulating, stabilizing and activating the cell-cycle inhibitor, p21, and is also capable of inhibiting the activities of cyclin-dependent kinase (CDK) 2 and CDK4, and E2F-mediated transcriptional processes, to block cell cycle progression (23-25). These mechanisms induce cell cycle arrest at the G1/S phase and inhibit cell proliferation. However, the activation of the PI3K/Akt signaling pathway has a negative regulatory role on the expression of $\mathrm{C} / \mathrm{EBP} \alpha(26)$.
The present study demonstrated that the proliferation of $\mathrm{HaCaT}$ cells was significantly increased and $\mathrm{C} / \mathrm{EBP} \alpha$ mRNA and protein expression levels were significantly decreased following treatment with 50, 70 and $90 \mathrm{ng} / \mathrm{ml} \mathrm{IL-17}$ for 24 h. Furthermore, downregulated expression of $\mathrm{C} / \mathrm{EBP} \alpha$ was detected in the psoriatic lesions, which was negatively correlated with PI. Therefore, the results of the present study suggest that IL-17 is capable of activating the PI3K pathway via IL-17R, and activation of the PI3K/Akt pathway may reduce the expression of $\mathrm{C} / \mathrm{EBP} \alpha$. Hence, IL-17 administration may inhibit keratinocyte proliferation by decreasing the expression levels of $\mathrm{C} / \mathrm{EBP} \alpha$, and $\mathrm{PI} 3 \mathrm{~K}$ may have a critical role in this mechanism.

In conclusion, IL-17 may result in the downregulation of $\mathrm{C} / \mathrm{EBP} \alpha$ expression in keratinocytes and the IL-17/C/EBP $\alpha$ axis may be associated with hyperproliferation of keratinocytes in psoriasis vulgaris lesions.

\section{References}

1. Bowcock AM and Kreuger JG: Getting under the skin: The immunogenetics of psoriasis. Nat Rev Immunol 5: 699-711, 2005.

2. Lynde CW, Poulin Y, Vender R, Bourcier M and Khalil S: Interleukin 17A: Toward a new understanding of psoriasis pathogenesis. J Am Acad Dermatol 71: 141-150, 2014.

3. Raychaudhuri SP: Role of IL-17 in psoriasis and psoriatic arthritis. Clin Rev Allergy Immunol 44: 183-193, 2013.

4. Nakajima K: Critical role of the interleukin-23/T-helper 17 cell axis in the pathogenesis of psoriasis. J Dermatol 39: 219-224, 2012.

5. Nerlov C: The C/EBP family of transcription factors: A paradigm for interaction between gene expression and proliferation control. Trends Cell Biol 17: 318-324, 2007.

6. Roe JS and Vakoc CR: C/EBP $\alpha$ : Critical at the origin of leukemic transformation. J Exp Med 211: 1-4, 2014.

7. Zaragoza K, Bégay V, Schuetz A, Heinemann U and Leutz A: Repression of transcriptional activity of C/EBPalpha by E2F-dimerization partner complexes. Mol Cell Biol 30: 2293-2304, 2010.

8. Johnson PF: Molecular stop signs: Regulation of cell-cycle arrest by C/EBP transcription factors. J Cell Sci 118: 2545-2555, 2005.

9. Oh WJ, Rishi V, Orosz A, Gerdes MJ and Vinson C: Inhibition of CCAAT/enhancer binding protein family DNA binding in mouse epidermis prevents and regresses papillomas. Cancer Res 67: 1867-1876, 2007.

10. Leonardi C, Matheson R, Zachariae C, Cameron G, Li L, Edson-Heredia E, Braun D and Banerjee S: Anti-interleukin-17 monoclonal antibody ixekizumab in chronic plaque psoriasis. N Engl J Med 366: 1190-1199, 2012.

11. Kagami S, Rizzo HL, Lee JJ, Koguchi Y and Blauvelt A: Circulating Th17, Th22, and Th1 cells are increased in psoriasis. J Invest Dermatol 130: 1373-1383, 2010.

12. Reich K: Anti-interleukin-17 monoclonal antibody ixekizumab in psoriasis. N Engl J Med 367: 274-275, 2012.

13. Papp KA, Leonardi C, Menter A, Ortonne JP, Krueger JG Kricorian G, Aras G, Li J, Russell CB, Thompson EH and Baumgartner S: Brodalumab, an anti-interleukin-17-receptor antibody for psoriasis. N Engl J Med 366: 1181-1189, 2012.

14. Kim HR, Cho ML, Kim KW, Juhn JY, Hwang SY, Yoon CH, Park SH, Lee SH and Kim HY: Up-regulation of IL-23p19 expression in rheumatoid arthritis synovial fibroblasts by IL-17 through PI3-kinase-, NF-kappaB-and p38 MAPK-dependent signalling pathways. Rheumatology (Oxford) 46: 57-64, 2007.

15. Gu C, Wu L and Li X: IL-17 family: Cytokines, receptors and signaling. Cytokine 64: 477-485, 2013.

16. Papp KA, Reid C, Foley P, Sinclair R, Salinger DH, Williams G, Dong H, Krueger JG, Russell CB and Martin DA: Anti-IL-17 receptor antibody AMG 827 leads to rapid clinical response in subjects with moderate to severe psoriasis: Results from a phase I, randomized, placebo-controlled trial. J Invest Dermatol 132: 2466-2469, 2012

17. Ramji D and Foka P. CCAAT/enhancer-binding proteins: Structure, function and regulation. Biochem J 365: 561-575, 2002 . 
18. Tada Y, Brena RM, Hackanson B, Morrison C, Otterson GA and Plass C: Epigenetic modulation of tumor suppressor CCAAT/enhancer binding protein alpha activity in lung cancer. J Natl Cancer Inst 98: 396-406, 2006.

19. Seifeddine R, Dreiem A, Blanc E, Fulchignoni-Lataud MC, Le Frère Belda MA, Lecuru F, Mayi TH, Mazure N, Favaudon V, Massaad C, et al: Hypoxia down-regulates CCAAT/enhancer binding protein-alpha expression in breast cancer cells. Cancer Res 68: 2158-2165, 2008.

20. Tseng HH, Hwang YH, Yeh KT, Chang JG, Chen YL and Yu HS: Reduced expression of C/EBP alpha protein in hepatocellular carcinoma is associated with advanced tumor stage and shortened patient survival. J Cancer Res Clin Oncol 135: 241-247, 2009.

21. Shim M, Powers KL, Ewing SJ, Zhu S and Smart RC: Diminished expression of C/EBPalpha in skin carcinomas is linked to oncogenic Ras and reexpression of C/EBPalpha in carcinoma cells inhibits proliferation. Cancer Res 65: 861-867, 2005.

22. Reckzeh $\mathrm{K}$ and Cammenga J: Molecular mechanisms underlying deregulation of C/EBPalpha in acute myeloid leukemia. Int J Hematol 91: 557-568, 2010.
23. Harris TE, Albrecht JH, Nakanishi $\mathrm{M}$ and Darlington GJ: CCAAT/enhancer-binding protein-alpha cooperates with p21 to inhibit cyclin-dependent kinase-2 activity and induces growth arrest independent of DNA binding. J Biol Chem 276: 29200-29209, 2001.

24. Wang GL, Shi X, Salisbury E, Sun Y, Albrecht JH, Smith RG, and Timchenko NA: Cyclin D3 maintains growth-inhibitory activity of C/EBPalpha by stabilizing C/EBPalpha-cdk2 and C/EBPalpha-Brm complexes. Mol Cell Biol 26: 2570-2582, 2006.

25. Rishi L, Hannon M, Salomè M, Hasemann M, Frank AK, Campos J, Timoney J, O'Connor C, Cahill MR, Porse B and Keeshan K: Regulation of Trib2 by an E2F1-C/EBP $\alpha$ feedback loop in AML cell proliferation. Blood 123: 2389-2400, 2014.

26. Datta J, Majumder S, Kutay H, Motiwala T, Frankel W, Costa R, Cha HC, MacDougald OA, Jacob ST and Ghoshal K: Metallothionein expressionissuppressedin primaryhumanhepatocellularcarcinomas and is mediated through inactivation of CCAAT/enhancer binding protein alpha by phosphatidylinositol 3-kinase signaling cascade. Cancer Res 67: 2736-2746, 2007. 